\title{
Influence of Fertilizers on the Components of Available Sucrose-Percent-Cane
}

\author{
George Samuels ${ }^{1}$ \\ INTRODUCTION
}

The influence of fertilizers on sugarcane tonnage has received much attention, and the literature on sugarcane abounds with details concerning this influence. There is not, however, very abundant information concerning the influence of fertilizers on the sucrose content of sugarcane. Most of the data available are concerned primarily with the gross effect of the fertilizer on sucrose-percent-cane without revealing the influence of the fertilizer on the factors upon which the available sucrose-percent-cane depends, such as polarization, Brix, or percentage of extraction.

These factors have more than passing interest to the staff of sugar factories whose task it is to obtain the highest yield of sugar from each ton of cane delivered to the mill. Such terms as extraction, Brix, and polarization may be abstract values to some cane growers, but they mean profit or loss to the factory man.

The object of this paper is to determine the influence fertilizers exert on the components of the available sucrose-percent-cane-polarization, Brix, and percentage of extraction. By revealing certain trends, it is hoped that a clearer picture may be obtained of the role of fertilizers and soil fertility in influencing the performance of sugarcane in the factory. An attempt is. also made to show what portion of a factory performance by a cane should be credited to fertility influences and what portion to such factors as variety and climate.

\section{PROCEDURES}

The data used for determining the influence of fertilizers on polarization, Brix, and percentage of extraction were obtained from sugarcane-fertilizer field experiments conducted by the Agronomy and Horticulture Department of the Agricultural Experiment Station of the University of Puerto Rico. Only those experiments which showed statistically significant effects from the use of fertilizer on the available sucrose-percent-cane were utilized in this work to determine the influence of the fertilizer on the individual components.

The experiments were laid out using split-plot, simple, randomized-block,

${ }_{1}^{1}$ Agronomist, Agricultural Experiment Station, University of Puerto Rico, Río Piedras, P. R. The author wishes to thank B. G. Capó, Associate Director for Research, for his comments and suggestions on this work. 
and triple-lattice designs. The majority of the experiments were replicated nine times; only two experiments had a minimum of six replications. The cane was cut as in commercial practice. Ten whole stalks of cane minus the tops were taken at random from each plot at the time of cutting. These canes were tagged as to origin, and were later ground in the hydraulic mill of the Agricultural Experiment Station at Río Piedras for determination of the sucrose content. All canes sampled were milled not later than 24 hours after cutting.

A hydraulic Squier mill was used which had two rollers, each one of which measured 12 by 16 inches. These rollers averaged 6.4 revolutions per minute, using a 10-horsepower Westinghouse electric motor, (1). ${ }^{2}$ The rollers exerted a pressure of 29 tons per square inch for the extraction of the juice from the cane passing through them.

The following procedures were used for the determination of available $96^{\circ}$ sucrose in the cane samples:

1. The 10-eane sample was weighed.

2. The cane sample was milled once and the bagasse also passed through once.

3. The juice obtained was weighed, and a representative sample taken for Brix and polarization.

4. Polarization and Brix were determined in the juice sample with a Baush and Lomb polariscope and a Zeiss refractometer.

5. Available $96^{\circ}$ sugar in the juice was calculated by using the following formula:

Available $96^{\circ}$ sucrose-percent-cane

$$
=\left(\frac{0.380329 \times \text { polarization }}{\text { Specific gravity } 20^{\circ} / 20^{\circ}}-0.41667 \text { Brix }\right) \times \text { percent extraction }
$$

The term "polarization" as used herein refers to the value determined by direct polarization of the normal-weight solution in a polariscope.

"Brix" or "degree Brix" as used herein is the percentage of solids dissolved in the juice as calculated from the index of refraction of the juice.

The term "percent-extraction" or "extraction" refers to the percentage of undiluted cane juice extracted from the cane sample by passing it through the hydraulic mill as described in step 2 of the procedures mentioned above. The weight of juice obtained divided by the weight of the sample milled and the quotient multiplied by 100 gives the percent-extraction. This term is not the same, but is comparable to the term "mill-extraction" used in the factory.

"Purity" is defined as the value obtained by dividing the sucrose in the juice by the degree-Brix and multiplying the quotient by 100 .

2 Numbers in parentheses refer to Literature Cited, p. 91. 


\section{RESULTS}

It is to be remembered that the results presented here are based on experiments wherein various fertilizer treatments produced significant influence on the yield of available sucrose-percent-cane. Those experiments in which no significant effect on available sucrose-percent-cane was evidenced were not utilized in this study, as it was reasoned that, if the total product, available sucrose-percent-cane, remained uninfluenced by the fertilizer treatment, it was very improbable that its various components could have been significantly influenced, even though in opposite ways. Therefore, the results should not be interpreted to mean that the mere use of a particular fertilizer element will produce the effect found here. Only when the fertilizer significantly influenced available sucrose content (2) were these effects obtained.

TABLE 1.-The influence of fertilizers on available-sugar components ${ }^{1}$

\begin{tabular}{|c|c|c|c|c|c|c|c|c|c|c|}
\hline \multirow{2}{*}{$\begin{array}{c}\text { Treat- } \\
\text { ment } \\
\text { No. }\end{array}$} & \multicolumn{3}{|c|}{$\begin{array}{l}\text { Fertilizer treatment, } \\
\text { per acre of - }\end{array}$} & \multirow{2}{*}{$\begin{array}{c}\text { Available } \\
96^{\circ} \text { sugar } \\
\text { juice }\end{array}$} & \multirow{2}{*}{$\begin{array}{c}\text { Available } \\
96^{\circ} \text { sugar } \\
\text { in cane }\end{array}$} & \multirow{2}{*}{$\underset{\text { Polariza- }}{\text { tion }}$} & \multirow{2}{*}{ Brix } & \multirow{2}{*}{$\begin{array}{c}\text { Extrac- } \\
\text { tion }\end{array}$} & \multirow{2}{*}{ Purity } & \multirow{2}{*}{$\begin{array}{c}\text { Relative } \\
\text { cane } \\
\text { tonnage } \\
\text { yields }\end{array}$} \\
\hline & N & $\mathrm{P}_{2} \mathrm{O}_{5}$ & $\mathrm{~K}_{2} \mathrm{O}$ & & & & & & & \\
\hline \multicolumn{11}{|c|}{. Nitrogen ${ }^{2}$} \\
\hline & Pounds & Pounds & Pounds & Percent & Percent & Degree & Degree & Percent & Percent & Percent \\
\hline 1 & 0 & 300 & 300 & $16.39 * *$ & $11,71^{* *}$ & $68.8 * *$ & $18.9^{* *}$ & $71.4^{*}$ & $86.5^{* *}$ & $52^{* * *}$ \\
\hline 2 & 125 & 300 & 300 & 17.56 & 12.68 & 73.7 & 19.8 & 72.2 & 88.4 & $83^{* * *}$. \\
\hline 3 & 250 & 300 & 300 & 17.66 & 12.75 & 74.1 & 20.0 & 72.4 & 88.0 & 100 \\
\hline
\end{tabular}

Phosphorus $^{3}$

\begin{tabular}{r|r|r|r|l|l|l|l|l|l|l}
\hline 4 & 300 & 0 & 300 & $15.71^{*}$ & $11.41^{*}$ & 67.8 & 19.1 & 72.4 & $82.0^{* *}$ & $82^{* * *}$ \\
$\mathbf{5}$ & 300 & 150 & 300 & 16.39 & 12.03 & 69.8 & 19.4 & 73.3 & 84.4 & 98 \\
6 & 300 & 300 & 300 & 16.40 & 11.93 & 70.4 & 19.8 & 72.7 & 82.7 & 100 \\
\hline
\end{tabular}

Potassium ${ }^{4}$

\begin{tabular}{r|r|r|r|l|l|l|l|l|l|l}
\hline 7 & 300 & 300 & 0 & $15.09^{* *}$ & $11.17^{* *}$ & $68.7^{* * *}$ & $19.7^{* * *}$ & 69.9 & $81.3^{* * *}$ & $88^{* *}$ \\
8 & 300 & 300 & 150 & 16.77 & 11.67 & $71.2^{*}$ & 20.0 & 69.6 & 83.8 & 97 \\
9 & 300 & 300 & 300 & 16.98 & 11.87 & 72.7 & 20.2 & 69.9 & 83.9 & 100 \\
\hline
\end{tabular}

1 The asterisks used in the table indicate that the treatment used significantly decreased the value as compared to that value for the treatment which follows: * indicates significant decrease at the 5-percent level, ** indicates significant decrease at the 1-percent level.

2 Average of 10 experiments.

${ }^{3}$ Average of 5 experiments.

${ }^{4}$ Average of 8 experiments. 


\section{NITROGEN}

Where the available sucrose-percent-cane was increased by the nitrogen applications, there was also an increase in polarization, Brix, purity, and percent-extraction (table 1). The average increase in polarization and Brix was highly significant to the first increment of nitrogen application to the soil (125 pounds $\mathrm{N}$ per acre) over the no-nitrogen treatment. The use of 250 pounds of per acre instead of 125 , however, did not give any appreciable increase (table 1) although cane yields were significantly increased up to the 250-pound-N-per-acre level.

\section{PHOSPHORUS}

The phosphorus-deficient cane showed significantly lower values in available sugar in juice and cane, purity, and relative yields (table 1). Variations in phosphorus applications did not significantly influence polarization, Brix, or extraction.

\section{POTASSIUM}

Significantly lower values were obtained for all factors except percentextraction when potash fertilizers were not used (table 1). Polarization values were affected strongly and gave significant increases at all fertilizer levels. Percent-extraction showed a smaller variation for different potassium levels than it did for either nitrogen or phosphorus.

\section{DISCUSSION}

When fertilizers had a significant influence on the available sugar content of the sugarcane, this influence was usually manifested in all of the components of sugar rather than in any one single component. In table 2, the relative responses of the components of sugar were compiled, based on the data of table 1. The no-fertilizer treatment of each of the three fertilizer elements was used as a base of 100 , and all subsequent increases or decreaseis were computed on this basis. It may be seen that of the components which were used to calculate available $96^{\circ}$ sugar, the polarization and Brix values were influenced to a greater extent than were percent-extraction and purity. The available $96^{\circ}$ sugar in juice and in cane showed a degree of response quite similar to polarization values for all three fertilizer elements (N, P, K).

The response of the components of available sugar to nitrogen fertilizers was favorable in the experiments utilized in this study. As can be seen from the relative cane yield, last column of table 1, the no-nitrogen cane (treatment 1) produced a severe deficiency of nitrogen as evidenced by relative yields, which declined to almost one-half that of the high-nitrogen treat- 
TABLE 2.-The relative responses of the components of available sugar to fertitizer treatments

\begin{tabular}{|c|c|c|c|c|c|c|c|c|}
\hline \multicolumn{3}{|c|}{$\begin{array}{l}\text { Fertilizer treatment in } \\
\text { pounds per acre of - }\end{array}$} & \multirow{2}{*}{$\begin{array}{c}\text { Available } \\
96^{\circ} \text { sugar in } \\
\text { juice } \\
.\end{array}$} & \multirow{2}{*}{$\begin{array}{l}\text { Available } \\
96^{\circ} \text { sugar in } \\
\text { cane }\end{array}$} & \multirow{2}{*}{ Polarization } & \multirow[t]{2}{*}{ Brix } & \multirow{2}{*}{ Extraction } & \multirow{2}{*}{ Purity } \\
\hline$N$ & $\mathrm{P}_{2} \mathrm{O}_{5}$ & $\mathrm{~K}_{2} \mathrm{O}$ & & & & & & \\
\hline \multicolumn{3}{|c|}{..} & \multicolumn{3}{|c|}{ Nitrogen } & & \multicolumn{2}{|l|}{. . } \\
\hline & & & Percent & Percent & Percent & Percent & Percent & Percent \\
\hline 0 & 300 & 300 & 100 & 100 & 100 & 100 & 100 & 100 \\
\hline 125 & 300 & 300 & 107 & 108 & 107 & 105 & 101 & 102 \\
\hline 250 & 300 & 300 & 108 & 109 & 108 & 106 & 101 & 103 \\
\hline \multicolumn{3}{|c|}{. } & \multicolumn{4}{|c|}{ Phosphorus } & ' & \\
\hline $250^{\circ}$ & 0 & 300 & 100 & 100 & $100^{\circ}$ & 100 & 100 & . 100 \\
\hline 250 & 150 & 300 & 105 & 105 & 103 & 102 & 99 & 103 \\
\hline 250 & 300 & 300 & 105 & 105 & 104 & 104 & 100 & 103 \\
\hline \multicolumn{3}{|c|}{ ' } & \multicolumn{3}{|c|}{ Potassium } & \multicolumn{3}{|c|}{ 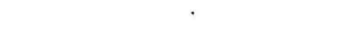 } \\
\hline 250 & 300 & 0 & 100 & 100 & 100 & 100 & 100 & 100 \\
\hline 250 & 300 & 150 & 105 & 105 & 103 & 102 & 99 & 103 \\
\hline 250 & 300 & 300 & 106 & 106 & 106 & 103 & 100 & 103 \\
\hline
\end{tabular}

ment (treatment 3). Where relative cane yields were 83 percent (treatment 2 ), the various sugar components gave no significantly different values from the high-nitrogen treatment (treatment 3).

But for phosphorus and potassium, with relative cane yields of 82 and 88 percent, respectively, the no- $\mathrm{P}_{2} \mathrm{O}_{5}$ and no- $\mathrm{K}_{2} \mathrm{O}$ treatments (treatments 4 and 7) had significantly lower values in the sugar components as compared with the high-fertilizer treatments (treatments 6 and 9). From a standpoint of relative cane yields deficiencies in phosphorus and potassium would make themselves felt in the components of available sugar before a nitrogen deficiency did so. In most cases in normal commercial practice, such severe nitrogen deficiencies as were developed under these experiments would not be encountered. In general, as evidenced by these data, one might expect the order of influence of the magnitude of a deficiency on available sucrose-percent-cane to be potassium $>$ phosphorus $>$ nitrogen.

The data so far reveal that fertilizers do influence the sugar content of cane and its component factors. However, it would not be fair to. leave the impression that fertilizers alone exert a powerful influence on sugar content. Such factors as weather; variety, and soil should be considered, for they also exert strong influences on sucrose content. At times the influence of 
TABLE 3.-The influence of fertilizers, varieties, weather, and soil on the components of available-sugar and cane yields

\begin{tabular}{|c|c|c|c|c|c|c|c|}
\hline Item & $\begin{array}{c}\text { Available } \\
96^{\circ} \text { sugar in } \\
\text { juice }\end{array}$ & $\begin{array}{c}\text { Available } \\
96^{\circ} \text { sugar in } \\
\text { cane }\end{array}$ & Polarization & Brix & $\underset{\text { tion }}{\text { Extrac- }}$ & Purity & $\begin{array}{c}\text { Cane yields } \\
\text { per acre }\end{array}$ \\
\hline
\end{tabular}

Fertitizer 1

\begin{tabular}{r|c|c|c|c|c|c|c}
\hline & Percent & Percent & Degree & Degree & Percent & Percent & Tons \\
150 pounds $\mathrm{K}_{2} \mathrm{O} \ldots \ldots$ & 15.12 & 10.31 & 67.6 & 20.3 & 68.2 & 74.5 & 50 \\
300 pounds $\mathrm{K}_{2} \mathrm{O} \ldots \ldots$ & 16.53 & 10.91 & 71.7 & 20.7 & 66.0 & 79.9 & 55 \\
\hline
\end{tabular}

Weather ${ }^{2}$

\begin{tabular}{l|l|l|l|l|l|l|l}
\hline Plant cane............ & 16.60 & 11.02 & 72.7 & 21.1 & 66.4 & 78.8 & 53 \\
Third ratoon......... & 16.44 & 11.64 & 70.2 & 19.7 & 69.0 & 83.4 & 54 \\
Fourth ratoon....... & 17.93 & 12.41 & 76.2 & 20.7 & 69.2 & 86.4 & 53 \\
\hline
\end{tabular}

Varieties $^{3}$

\begin{tabular}{|c|c|c|c|c|c|c|c|}
\hline M. 28. & 16.95 & $12.22 ：$ & 71.2 & 19.7 & 72.1 & 86.0 & 34 \\
\hline P.O.J. $2878 \ldots$ & 15.24 & 10.96 & 65.7 & 18.9 & 71.9 & 80.6 & 42 \\
\hline P.R. $902 \ldots \ldots$ & 17.17 & 12.07 & 72.0 & 19.8 & 70.3 & 86.7 & 62 \\
\hline
\end{tabular}

Soil and weather ${ }^{4}$

\begin{tabular}{l|l|l|l|l|l|l|l}
\hline Coto clay............ & 15.24 & 10.96 & 65.7 & 18.9 & 71.9 & 80.6 & 42 \\
Coloso silty clay..... & 17.93 & 12.41 & 76.2 & 20.7 & 69.2 & 86.6 & 53 \\
Fraternidad clay..... & 14.50 & 10.47 & 67.8 & 19.7 & 72.2 & 73.6 & 33 \\
Vía silty clay........ & 17.44 & 12.26 & 73.6 & 20.1 & 70.3 & 86.8 & 41 \\
\hline
\end{tabular}

${ }^{1}$ Variety P.O.J. 2878, second ratoon, at Arecibo; all treatments received 250 pounds $\mathrm{N}$ and 300 pounds $\mathrm{P}_{2} \mathrm{O}_{5}$ per acre.

${ }^{2}$ Variety P.O.J. 2878, at Arecibo; all treatments received 250 pounds $\mathrm{N}$ and 300 pounds $\mathrm{P}_{2} \mathrm{O}_{5}$ and $\mathrm{K}_{2} \mathrm{O}$, per acre.

${ }^{3}$ Third ratoon, at the Isabela Substation, all varieties received 250 pounds $\mathrm{N}$ and 300 pounds $\mathrm{P}_{2} \mathrm{O}_{5}$ and $\mathrm{K}_{2} \mathrm{O}$, respectively, per acre.

:Variety P.O.J. 2878; all soils received 250 pounds $\mathrm{N}$ and 300 pounds $\mathrm{P}_{2} \mathrm{O}_{5}$ and $\mathrm{K}_{2} \mathrm{O}$, per acre.

weather, soil, or variety may mask the influence of fertilizers on sugar content. Examples of the influences of fertilizer, weather, soil, and variety on sugar and components are given in table 3 . The data were taken from field experiments, and so compiled that the only stated factor was the variable and all other experimental conditions were kept as constant as possible. One can readily see that variations as great as, or greater in magnitude than those obtained with fertilizers were obtained with such factors as 
varieties, soil, and weather. Therefore, all data concerning the influence of fertilizers on sugar and its components must be evaluated carefully to insure that such factors as variety, soil, and weather are not responsible for the influence found or cited.

\section{SUMMARY}

Using data from experiments where fertilizers had significantly influenced available sucrose-percent-case yields, the influence of the fertilizers on the various components of sugar in sugarcane were found to be as follows:

1. When sufficient potassium was present, nitrogen applications increased polarization and degree-Brix very significantly, and percent-extraction to a lesser degree.

2. A deficiency of phosphorus significantly decreased sucrose both in juice and in cane, as well as purity.

3. Potassium deficiencies produced highly significant reductions in available sugar in juice and cane, polarization, Brix, and purity. Percent-extraction was not significantly influenced by use of potash fertilizers.

4. The relative responses to the fertilizer treatments were highest for available sugar in both juice and cane, and in polarization, with degreeBrix following. Percent-extraction showed the lowest relative response to the use of fertilizer.

5. The roles of weather, soils, and variety as compared to fertilizers in influencing sugar and its components are discussed, because their effects must be distinguished from the influence of fertilizer.

\section{RESUMEN}

Cuando se usaron datos demostrativos de que los abonos influían significativamente sobre el por ciento de sacarosa en los rendimientos de la caña de azúcar, se encontró que la influencia de estos abonos sobre los varios componentes del azúcar fué como sigue:

1. Cuando hubo suficiente potasio presente, las aplicaciones de nitrógeno aumentaron muy significativamente la polarización y el grado de Brix. La presencia de potasio influyó en un grado menor en cuanto al por ciento de extracción.

2. Una deficiencia en fósforo redujo significativamente la sacarosa, tanto en el jugo como en la caña y también aminoró la pureza del jugo.

3. Las deficiencias en potasio produjeron reducciones altamente significantes en el azúcar disponible en el jugo y en la caña, en la polarización, en el grado de Brix y en la pureza del jugo. El por ciento de extracción no fué afectado significativamente por el uso de los abonos potásicos.

4. El grado relativo de responder a los tratamientos con abonos fué 
más alto en cuanto al azúcar disponible, tanto en el jugo como en la caña, y en la polarización, siguiendo en este respecto el grado de Brix.

5. Se discutieron los efectos del clima, de los suelos y de las variedades en lo que se refiere a su influencia sobre la producción del azúcar y la variación de sus componentes, porque debe distinguirse de la que ejerce el abono.

\section{LITERATURE CITED}

1. Riollano, Arturo, Nuevas variedades de caña de azúcar, Univ. P. R., Agr. Exp. Sta. Bul. 91, Aug. 1953.

2. Samuels, G., Lugo-López, M. A., and Landrau, P., Jr., Influence of fertilizers on sucrose content of sugarcane, Sugar 47 49-51, 1952. 